\title{
A Study on Reconciliation of Post-War
}

\section{Peacebuilding in Sri Lanka}

\author{
Menik Wakkumbura ${ }^{1}$ and Nirmali Wijegoonawardana ${ }^{2}$ \\ ${ }^{1}$ Consultant, Head/ Centre for Language Studies, Sri Lanka Institute of Development \\ Administration. \\ ${ }^{2}$ Senior Lecturer, Dept. of History, University of Colombo.
}

\begin{abstract}
Since the end of war in Sri Lanka in 2009, the landscape of the reconciliation process has come under critical debate. In response, the Sri Lankan government efforts in reconciliation and all other types of efforts are seemingly on increase for achieving peace. In this light, the paper critically examines both practice and theoretical development of how "justice" in the reconciliation can impact on "positive peace" as a greater peacebuilding effort evident to be useful in post-war Sri Lanka. It is debated how reconciliation experienced at all societal layers have considered "justice" as a prerequisite for successful outcomes. Therefore, given the empirical evidence, the paper has prioritized how social justice, removal of cultural barriers and consideration on a wider scope of human rights, regarded in "justice" become a core contributory factor of Sri Lanka's reconciliation. And these attempts lead for structural changes using of different peacebuilding approaches i.e., "national" and "grassroots". However, in Sri Lanka reconciliation has experienced a number of vital challenges. These challenges are the complex nature of the process, broken consensus on "justice" among people, politicized decision-making, policy gaps and many more. While investigating important empirical findings about the reconciliation process in Sri Lanka, the paper critically examines the use of different reconciliation approaches and how far "justice" has been criticized within the implementation. The study has utilized content analysis and a descriptive narrative to examine the research problem. The discussion arrives at a conclusion of using of both national and grassroots peacebuilding approaches and serious emphasis on "justice" would let reconciliation to be closer in achieving "positive peace". The discussion also reveals the complexities of such achievements unless addressed on "trap" conditions i.e., lack of economic reconstruction, social and emotional competencies, trust, healing and forgiveness.
\end{abstract}

Key Words: Reconciliation, Justice, Peacebuilding, Positive Peace, Sri Lanka 


\section{Introduction}

Reconciliation has the capacity to focus on a range of themes, mechanisms and practices that combine to form the thread of the national reconciliation process (Gibson, 2004; Lederach, 1997). In particular, countries which have experienced civil wars and ethnic strives have experienced reconciliation as a process that was particularly challenging. This paper sheds light on how with respect to the reconciliation process in Sri Lanka; "justice" as a prerequisite for the reconciliation process hindered the attempt to achieve "positive peace". In addition, how "justice" was less applied and monitored when implementing different reconciliation efforts in Sri Lanka. "Justice" poses itself as one of the most complex and multifaceted areas not only in terms of normative implication but also as a pragmatic concern for actual peace, thereby contributing to existing literature as well as easing further academic efforts at understanding the dynamics of "justice" in the reconciliation process in Sri Lanka, the paper expanses this discussion.

This paper however, therein lays the paradox of any reconciliation process, which is deciphering at an early stage which approach is most suitable and be most compensating towards achieving "justice" until a form of "positive peace" is achieved. The three prominent terminologies i.e., justice, positive peace and reconciliation are often linked to the natural reconciliation process as either means, or as an end result, according to the authors' argument. The reconciliation process composes of a multitude of models and possesses a multitude of conceptual uses claiming to depart from the ideal model for establishing an agreeable meaning and an ideal model. When opening scholarly overviews about Sri Lanka's reconciliation process during and aftermath of war, the reconciliation process seems to have been detached from the mainstreamed political process and remained unregulated in the country (Uyangoda, 2013). Much of the cause for the failure of the reconciliation process in Sri Lanka was due to politically motivatedethnic disagreements, prolonged issues relating to ethnic solitudes at a national level, and wide social and economic inequalities (Perera, 2012). In addition to this, there were numerous disagreements regarding democratic legitimization of political and civil institutions, despite the lack of contribution towards a long standing solution. Based on such empirical experiences local and international scholars have offered far-reaching 
interpretations to the reconciliation process in the country ${ }^{\mathrm{i}}$. They consider reconciliation as a complex process and perceive it as a challenge due to its incompatibility with unplanned policies.

The paper sheds light on a critical debate on how reconciling "justice" becomes an essential matter, and when "justice" is accomplished as a pre-requisite to many focuses the problematic issues in peacebuilding are eliminated. This paper broadens its scope by considering various arguments related to the "grassroots" and "national" approaches of peacebuilding for implementing "justice" in the reconciliation process in Sri Lanka. It is impossible to comprehend the rate of success of an actual reconciliation process without reviewing the broader issues at hand and examining them for possible outcomes; which this paper will not focus on. However, the paper opens a critical debate of understanding how the reconciliation process in Sri Lanka particularly after the war in 2009 has contributed towards "justice" enabling "positive peace"ii . In this overall examination, the paper examines post-war Sri Lanka essentially to find "reconciliation" as a fundamental mechanism. However, academic debates have criticized Sri Lanka for being less effective in considering "justice" in the form of transnational justice (Hogland and Orjuela, 2013). These scholars further argue, that "justice" should not only be considered within the field of transitional justice but also as justice in everyday forms of living such as the ability to engage in economic, social and political spheres; also at community and national levels. In this regard, the following section of this paper poses an important premise for an epistemological and ontological examination of Sri Lanka`s reconciliation process in a multidimensional aspect.. The examination is about the deep rooted causes of "justice" achievable through peacebuilding. Hence, this discussion provides a unique analysis to the answer on theoretical debates and unsolved questions related to the challenging nature of "justice" in the reconciliation process of Sri Lanka.

\section{Research Problem}

The problem in Sri Lanka is emerged within the basic agreement about reconciliation; its process and implementation are being challenged for lasting peace (terminologically called as "positive peace"). In Sri Lanka, on the one hand, reconciliation is viewed as a social process which aims co-existence of ethnic groups and willingness to accept a 
common future. On the other hand, reconciliation is a government attempt for transforming institutional and constitutional means for a greater status-quo. However, such attempts seek how people-to-people approach can impact over ethnic and religious harmony, responsible for plurilingualism, social justice in the societal levels have been clearly problematic. The authors view this as a critical issue related to both reconciliation attempts and its main prerequisite known as the "justice" aspect also Sri Lanka's less willingness for mutual acceptance on national and grassroots peace approaches over a period. With this explanation, the reconciliation process can be questioned with reference to its overall nature, process and implementation. The problem occurs not only in the above areas and its complex scope and remedial actions for peacebuilding, and in the authors view on the need of structural changes not as an end goal but as a mean for achieving relatively effective peace in the society.

\section{Justice, Positive Peace and Reconciliation}

Reconciliation as one of the most complex and unique mechanisms in peacebuilding, therefore, naturally acquires various definitions i.e., "building of broken relationships" (Tutu, 2007), and "re-establishing harmony of a society in a reciprocal manner" (Fisher, 2001). The psychological aspect of reconciliation can be to: "replace negative attitudes" (Kriesberg, 2014) and the moral approach would be to "recognize the injustice done, by deciding the healing process" (Montiville, 1993). However, according to widely available definitions; reconciliation is equal to the healing process, which encompasses the terms "closure", meaning the prevention of further hostilities and also the term "healing", meaning rehabilitating individuals affected by the war (Galtung, 1996). Also, reconciliation can be considered in two perspectives- one as a "process" and the other as an "outcome". The outcomes are physical, psychological and attitudinal in scope (Van der Merwe 1999; Hirsch, Mackenzie \& Sessay 2012). For example, South Africa's reconciliation has clear constitutional and judicial outcomes; furthermore, it has held various processes related to transnational justice, forgiveness through collective and individual amnesty, healing and truth-telling (Tutu, 2007). Reconciliation in Nepal similar to the South African national reconciliation process, established a Truth and Reconciliation Commission (TRC) and various state level formations to recognize war victims. However in Nepal, the TRC has functioned without compensatory obligations 
(Adhikari \& Hansen, 2013). These pragmatic experiences show how reconciliation as a functional mechanism for healing and truth-seeking establishes differently in post-war societies. Sri Lanka`s national reconciliation process, according to the proposed and National Policy on Reconciliation consists of six (06) vital aspects i.e., equity, human rights, inclusivity and diversity, justice and rule of law, ownership, and clear and constant communication (2016).

World literature shows "justice" in reconciliation, addresses the wrong-doing or responds to the wrong-doing (Schreiter, 2004). Also how accomplishing "justice" during a reconciliation process includes "punitive justice"; meaning the moral responsibility of wrong-doing; moreover the widely accepted transitional justice focuses on "retributive justice" and "restorative justice" meaning that the perpetrators of the act of wrongdoing are proportionately punished and perpetrators are forced to take responsibility for repairing the harm they have caused ${ }^{\mathrm{iii}}$. As per the point of view of social justice, reconciliation constitutes a "just" outcome. Literature on this is best explained through "transitional justice" (Cassesse, Tutu, 2009). Antonio Cassesse argues that reconciliation is essential to meeting with national justice processes that adhere to a) collective amnesia and b) general amnesia with regards to perpetrators (1998). He argues how the judiciary process can support reconciliation by accepting and promoting true forgiveness for wrong doing. Also, "justice" serves as a multi-faceted form for healing processes. "Justice" in liberal and economic perspective inclines a "critical" perspective in modern debates, thus associating a boarder social and economic development. This challenges the old school notion of liberal justice by establishing liberal democracies and market economies (Adhikari and Hansen, 2013).

These essential components are explained well in the "continuum of peace" theoretically distinguished by John Galtung's writing titled Violence, Peace and Peace Research (1969). He has profoundly conceptualized how the aspect of "negative peace" is separate from the aspect of "positive peace" and how well justice concerns will be prevailed over violence. Further he explains "positive peace" as a prerequisite for sustainable peace in peacebuilding. The structural developments in peace attainment contain numerous establishments such as relief, rehabilitation and reconciliation (Richmond and Tellidis, 
2012). Galtung's model (1969) comes closest to conflict analysis and conflict transformation synthesis. It recognizes the meaning of "conflict" in a broader perspective by understanding the "conflict" in a more specific context. His arguments re-examined by two prominent scholars in the field of conflict resolution, named Edward Azar (cited in Ramsbotham, 2005) and John Burton (1984) reinforced constructive conflict handling through structural and cultural approaches in conflict transformation. These pragmatic applications tend to investigate how far attitudes, contradictions and behaviors are functioning over a conflict and conflict resolution. More specific to the main concern of this paper, is the term "justice", as reconciliation during post- conflict peacebuilding is immersed in cultural and a social condition in which exploitation is minimized and neither overt violence nor the phenomenon of underlying structural violence could be evident. Structural peace developments thus emerge in "positive" upon "negative" peace means. In other words explanation related to the "positive" aspect clearly endorsed "justice" by considering that; establishment of social justice, removal of cultural barriers, self-realization which means much personal choice, meeting basic human needs (rights), economic and social wellbeing and environmental balance are attained. This elaboration restates "justice" as a clear prerequisite for "positive peace" in which reconciliation plays a vital role in peacebuilding.

\section{Sri Lanka's Reconciliation Process}

Sri Lanka's reconciliation process requires an analysis with a strong understanding of the entire destruction caused by the civil war and the circumstances that caused the civil war to extend for thirty years ${ }^{\text {iv }}$. The number of direct and indirect war affected causalities, deaths; property loss, remaining refugees, ex-LTTE combatants and overall psychological and economic loss become an important aspect for critical examination. These aspects either directly or indirectly cause injustice in society. According to statistics released by the Government Census and Statistics Department (2012) an estimate of 6858 people died between January and May 2009, the first five months of 2009. A peak in the number of casualties in Sri Lanka appears in 2009 according to the Uppsala Conflict Data Program. According to the United Nations Humanitarian Coordination Office the total number of deaths amount to $80,000-100,000$ people during the 
years spanning from 1983-2009 (United Nations, 2012). During the same period thousands were internally displaced. The economic consequences as stated by Saman Kelagama (1999) show how war had caused the country to incur an "enormous economic cost" in terms of investment and production cost, not to mention, the psychological damage caused by the war which is incalculable (cited in Rotberg, 1999).

However, considering Sri Lanka's post-war recoveries, significant achievements have been made on economic, social and political terms. Those rehabilitation and reintegration programs during the years between 2009 and 2011 became significant in the process of peacebuilding. The programs related to reintegration showed different national peace approaches used in the country. These rehabilitation programs have focused on victims of war, captured combatants and the perpetrators belonging to the Liberation Tigers of Tamil Elam (referred to as "LTTE" hereafter) during Elam war III and Elam war IV. In these programs, the total number of rehabilitees amounted to 12,167 by the year 2013 and those who have been reintegrated total to 11,002 (The Bureau of the Commissioner General of Rehabilitation, Sri Lanka, 2014). In addition to this, the total number of resettlements of conflict induced communities from the Northern and Eastern provinces have been totaled as 232,828 families and 796,342 persons by the end of May 2015 (Ministry of Resettlement, 2015).

While these reconciliation programs have produced a significant number of rehabilitees and resettlements, in 2011 the Lessons Learnt and Reconciliation Commission (referred to as "LLRC" hereafter) had recommended a legal and political solution for lasting peace. In order to implement these decisions, the government had formed a National Action Plan (NAP) in 2012 to undertake the assignment. Also the drafted National Policy on Reconciliation in 2012 had proposed a multi-ethnic, multi-party and home-grown solution. In addition to this, Sri Lanka's National Policy Framework for Social Integration has been aimed at ethnic co-existence and needful co-relational social engagements between three (03) main ethnic groups in the island ${ }^{v}$. More importantly the Paranagama Commission established in August 2013 and The Paranagama Report ${ }^{\mathrm{vi}}$ produced in 2015, claimed for an independent judiciary inquiry process for war crimes. This Commission reinstated the LLRC concerns on state actions for crime and missing 
persons' issues, and the government to establish a special commission titled "Presidential Commission to Investigate into Complaints Regarding Missing Persons". Moreover, the state institutional and policy establishments since 2015 are multiple to address the question left delayed on reconciliation. Among some of the vital institutional establishments i.e., Office for National Unity and Reconciliation (ONUR) in 2016 and draft National Policy on Reconciliation, and ministerial portfolios such as, Ministry of National Integration and Reconciliation, and the Ministry of National Coexistence Dialogue and National Languages. The Secretariat for Coordinating Reconciliation Mechanism attached to the Prime Minister's Office took over monitoring the Office of Missing Persons, Truth, Justice, Reconciliation and Non-Recurrence Commission, Judicial Mechanism and Office of Reparations.

However, the provocative "national" reconciliation in Sri Lanka has largely concentrated on contracted institutional realizations, political (re)formation related to ethnic harmony and territorial-based devolution of power. These mechanisms and institutional forms are taking a prolonged time for finding remedial measures on crucial issues such as land resettlements, offering basic needs to the those affected by war, and issues on larger social and economic needs; thus leaving an unsolved problem in the country. Critics show many reconciliation attempts as mere political promise rather than a deliberate peacebuilding attempt ${ }^{\mathrm{vii}}$. Also, heavy critics over certain major changes concentrated after the war were about economic reconstruction and establishing infrastructural necessities and few market goals in the North and East of Sri Lanka.

Given the emphasis on the critical question of reconciliation, most issues at a community level seem to have not been effective for the healing of victims' grievances and granting necessary human needs for re-establishing their lives. The economic deprivation and low market place opportunities, truth-telling and healing within liberal and social perspectives remain areas that have been considered the least. The anthropological study held by Jayawickreme et.al (2012) stressed that the actual psychological well-being of individuals who have been traumatized during the war has not been tackled (2012;130-135). Not only the psychological concerns but also the economic deprivation in the North and East are wide-spread issues that continue to challenge the reconciliation process (Kelagama, 
2013). These fundamental aspects of reconciliation therefore become important for scrutiny. The prevailing experiences bring an empathetic inception for investigating further on the issues at "grassroot" levels. In fact evidence least prioritized, yet are vital aspects of reconciliation over the last seven years, have elevated the trapped nature of the reconciliation process adding multiple angles to the "justice" scope. It is further apparent when reviewing economic and socio-political debates in local literature. The national level economic development programs known as the development of the East "Neganahira Navodaya" and development of the North, "Uthuru Wasanthaya" in the 180-days plan during 2010-2011 resulted in some major infrastructural developments within the war affected areas (Kelegama \& Abayasekera, 2012). The liberalists have showed how the post-war rapid economic growth island-wide, improved Gross Domestic Production by increasing it from a 3.5\% in 2009 to a 7.3\% in 2013. However, despite the improvement of the economy, unemployment still remained high in the North and East (Central Bank, 2013; Kelegama, 2013). Added to these criticisms, the current political regime has looked for a strategic economic direction for poverty elimination in some of the economically parallelized districts such as Mannar, Mullaitiuv, and Kilinochchi which were the districts worst affected by the war. Arguments portray how the economic factor was one of the core contributory factors; yet how it failed in supporting a sustainable form of peace and failed to aid in post-war recoveries. However, as to scholarly arguments the only significant outcome too was the economic factor that has overlooked sustainable economic development as a foremost establishment to many conflict grievances (Uyangoda, 2013).

Relevance to the emphasis on de-militarization and re-integrating of communities directly combat in the war there have also not been successful attempts for the last six years. Rajasinham-Senanayake used the phrase "mission and mandate creep" to highlight the continuous military presence in the war torn areas (2011). Also, according to Hoglund and Orjuela (2013) those grievances of minorities have not been dealt with, hence there is no transition from a militarized society to a non-militarized society $(2013 ; 307)$. The LTTE combatants who surrendered and were recorded as 11, 644 individuals in 2009, have been reintegrated to their native societies. Yet, a number of local researches which 
examined the $D_{D R}^{\text {viii }}$ processes have arrived to a grounded conclusion on the unsuccessful and challenging nature of the DDR process and how these repercussions deeply cause issues to actual peace realizations. These arguments show how community development and capacity building of victims and former LTTE combatants have become problematic for individuals in societal transformation aiming for better integration. Also how alterations can be made for the future, on the former LTTE combatants not yet well thought out.

The problem in Sri Lanka emerges within the basic agreement on how difficult issues on "justice" relevant to the reconciliation process, contribute less toward structural changes aimed at "positive peace". If structural changes mean establishment of a wide variety of social justice, removal of cultural barriers, and meeting with human rights, the question in Sri Lanka about successful reconciliation remains highly unattained. These critical issues lead the country to a trapped position as argued by authors. The trap covers with insufficient distribution of social and economic resources, un-attended single issues related to war crimes, missing persons, initiation of truth-telling and healing processes, and aspects related to reparation and transitional justice. Further, the trap will be more stiffed due to poor policy directions. The problem has become worse when reconciliation i.e., "grassroots" and "national" as a whole contributes less towards generating a common consensus over a type of Sri Lankan reconciliation process. These issues thus pertaining to people's levels (victimizer and victim both inclusively) and in the community level widen the problem. In addition, the dual model of Sri Lanka's reconciliation i.e., a social process which aims at co-existence between ethnic groups and the willingness to accept a common future, and reconciliation as an attempt made by the government for transforming institutional and constitutional means for a greater status-quo, is adding multiple means to the local debates. However, such attempts attempt to portray how a people-to-people approach can impact ethnic and religious harmony, responsible for plurilingualism, social harmony; equal rights and equity in greater choices at a societal level become unclear. These aspects cover a large scope of social injustice. The pertaining unequal choices and limited resources for achieving adequate justice at an individual and societal level hinder "positive peace". Else the number of policy 
formulation, institutional establishments and related all national consultation processes are less collective for better distribution of resources and implementing decisions through skillful workforce in the line of national aims.

\section{The Critical Question on “Justice” Pertains}

Among some of the vital scholarly discussions about the usefulness of establishing "liberal peace" and ethnic and social integration shows, how economic development mitigates societal harm. This was the foremost consideration since the end of the war in Sri Lanka thus hiding the trapped outlook of the reconciliation process. Authors such as Sanmugaratnam and Stokke (2008) in their study explain the government's readiness for immediate actions over rehabilitation and resettlement of war victims have never been contributory toward a successful economic development of the North and East (pp. 99102). Not only the economic issues but also problems within displacement, psychological trauma and psychological wellbeing of those in the North and East since 1980, with the emergence of direct military confrontation have destroyed the wellbeing of the civil society over many decades. These scholarly debates claimed the importance of the social psychological impact of the war to be healed, rebuilding of physical infrastructural damage, targeted mental health services, and ramifications as key factors of a reconciliation process in Sri Lanka. Also national policy literature have identified prominent characteristics specific to the scope and interest of unique reconciliation

processes and the question on how "reconciliation" is context specific, challenging and dynamic. Added to many criticisms, the Final Full Report of the Consultation Task Force on Reconciliation Mechanism (CTF, 2017) explains;

"... Grave concerns were expressed in the submissions about ongoing human rights violations in the North and East, including allegations of abductions and incidents of intimidation of victims and human rights defenders. The continuation of these incidents is a matter of serious concern, having a detrimental impact on the credibility of the Transitional Justice process (2017, p.3)".

Having stated that, the Report has examined the poor performance of the overall tasks related to "justice" i.e., disappearances, rights to the victims and survivors, firm and regular investigations (mechanism), resource sharing and awareness and many other 
institutional structuring for better implementation of the policy. In addition, criticism show the use of the process of healing and enhancing inter-ethnic harmony and coexistence has to come from within Sri Lanka, its people and its Government (2015). Also how the least understanding about the meaning and use of reconciliation far severely impact the poor performance of "justice" accomplishments. The United Nations in their Report to the Government in 2016 explains "fostering a process of closure and accountability and listening to the views and opinions of the victims and survivors who will prioritize different aspects of transitional justice" (2016, 9-10). It is a question how much deliberately the victims and survivors can contribute with a proper feedback. When assessing these claims reported at a policy level, despite the number of reconciliation attempts that have been made in the country, Sri Lanka is yet to use a right tracked reconciliation process which is crucial. In addition to this, within the role "justice" a space for promoting state legitimization, progressive politics and economic justice become questionable to any grassroots person.

\section{Conclusion}

The revoked idea of a successful reconciliation in multiple means specially attending to transitional justice concerns, reparations, concerns over human rights and institutional and policy level reformations making a significant improvement in the country. The findings highlight the prolonged nature of the issue(s) pertaining not only to the mere scope of reconciliation but also to the number of questions around "justice"; continuously challenging any successful outcome. The paper shows how Sri Lanka has been less contributory in any successful continuation and with the regime change in 2015 there has been a change in the reconciliation direction from economic to a more social and political context by addressing some of the vital concerns raised by the Human Rights Commission on justice and human rights aspects ${ }^{\mathrm{ix}}$. The findings also show some of the worst affected ideological and physical damages being highly influential over successful reconciliation at an individual level. Hence, it would appear that Sri Lanka is at stake when considering progressive reconciliation, the present and future. Also, meeting with human rights concerns, truth-telling and transitional justice have become major tasks that require firm planning and collective institutional and policy level developments. Despite 
heavy concentration over economic recoveries until 2015, the country continues with economic attainment a valid proposition as the paper examined. As mentioned in the main discussion the CTF 2017 Report highlights some of the major drawbacks that Sri Lanka immediately should attend to and correct. These well examined policy directions and reporting is on the one hand a guide for future actions. Also the Report convinces the foreign audience - who are very keen about domestic reconciliation and peacebuilding endeavors for being supportive. Sri Lanka as is a small nation, it is essentially important to tie-up with the international system for better performance of reconciliation, so that the "trap" could be removed. In addition, as discussed under several vital themes the peopleto-people support and the national-to-people and people-to-national support as per authors preference to be called as "grassroots" and "national" reconciliation become inevitably important for diminishing of unknown statuses of what reconciliation is meant by Sri Lanka. The authors define these situations as virtual and physical "trap" conditions. Given the enormous amount of literature and timely up-dated information, the paper presents the nature of the reconciliation process in Sri Lanka, and how if we are to attain fruitful results the gradual and holistic consideration over "justice" is to be thoroughly maintained so that positive and sustainable peace become realistic in the country.

\section{References}

Adhikari, P., \& Hansen, W. L. (2013). Reparations and Reconciliation in the Aftermath of Civil War.Journal of Human Rights, 12(4), 423-446.

Burton, J. W. (1984). Global conflict: The domestic sources of international crisis. University of Maryland Center for Intl.

Cassese, A. (1998). Reflections on international criminal justice. The Modern Law Review, 61(1), 1-10.

Census and Statistics Department Sri Lanka, (2012). Census of Population and Housing. Fisher, R. J. (2001). Social-Psychological Processes in Interactive Conflict Analysis and. Reconciliation, justice, and coexistence: Theory and practice, 25.

Galtung, J. (1969). Violence, peace, and peace research. Journal of peace research, 6(3), 167191.

Galtung, J. (1996). Peace by peaceful means: Peace and conflict, development and civilization (Vol.14). Sage. 
Gibson, J. L. (2004). Does truth lead to reconciliation? Testing the causal assumptions of the South African truth and reconciliation process. American Journal of Political Science, 48(2), 201-217.

Goodhand, J. (2010). Stabilising a victor's peace? Humanitarian action and reconstruction in eastern Sri Lanka. Disasters, 34(s3).

Hoglund, K., and Orjuela, C. (2013). Friction and the pursuit justice in post-war Sri Lanka. Peacebuilding, Vol.1, No.3, 300-316.

Hirsch, M. B. J., MacKenzie, M., \& Sesay, M. (2012). Measuring the impacts of truth and reconciliation commissions: Placing the global 'successes of TRCs in local perspective.

Cooperation and Conflict, 47(3), 386-403.

Kelegama, S. (2013). Export sector in Sri Lanka: Issues and Challenges institute of policy studies of Sri Lanka. National chamber of Exporters of Sri Lanka.

Kriesberg, L. (2004). Comparing reconciliation actions within and between countries. From conflict resolution to reconciliation, 81-110.

Lederach, J. P. (1997). Building peace: Sustainable reconciliation in divided societies. Washington DC, 4.

Montville, J. V. (1993). The healing function in political conflict resolution. Conflict resolution theory and practice: Integration and application, 112-127.

Office of the National Unity and Reconciliation, (2016). (Draft) National Policy on Reconciliation Sri Lanka.

Perera, J. (2012). Political challenges in post-war Sri Lanka. Institute of South Asian Studies, National University of Singapore.

Ramsbotham, O. (2005). The analysis of protracted social conflict: a tribute to Edward Azar. Review of International Studies, 31(01), 109-126.

Richmond, O. P., \& Tellidis, I. (2012). The Complex Relationship between Peacebuilding and Terrorism Approaches: Towards Post-Terrorism and a Post-Liberal Peace? Terrorism and Political Violence, 24(1), 120-143.

Schreiter, R. (2004). The theology of reconciliation and peacemaking for mission. Mission, Violence, and Reconciliation. Sheffield: Cliff College Publishing, 11-28.

Shanmugaratnam, N., \& Stokke, K. (2008). Development as a precursor to conflict resolution: A critical review of the fifth peace process in Sri Lanka. Between war and peace in Sudan and Sri Lanka: Deprivation and livelihood revival, 93-115.

The Bureau of the Commissioner General of Rehabilitation, Sri Lanka, (2014). Sri Lanka's rehabilitation Programme.

The Consultation Task Force on Reconciliation Mechanism (CTF). (2017) Final Report: Paranagama Commission, Sri Lanka. 
Van der Merwe, H. (1999). The truth and reconciliation commission and community reconciliation: An analysis of competing strategies and conceptualizations (Doctoral dissertation, George Mason University).

United Nations, (2016). "Promoting reconciliation, accountability and human rights in Sri Lanka", Human Rights Council, A/HRC/32/CRP.4.

United Nations, (2012). United Nations Humanitarian Co-ordination Office, Retrieved from: https://docs.unocha.org/sites/dms/Documents/OCHA_Brochure_Eng_2012.pdf

United Nations, (2012). Secretary General's Internal review Panel of United Nations Actions in Sri Lanka, Geneva: United Nations.

Uyangoda, J. (2013). Healing after war: thinking beyond the solitudes. In D. Herath and K.T.Silva (eds), Healing the Wounds-Rebuilding Sri Lanka after the war, Sri Lanka: International Centre for Ethnic Studies. pp. 18-22.

Uyangoda, J. (2010). Politics of political reform - a key theme in the contemporary conflict. Power and politics, 29.

Tutu, D. M. (2007). Reflections on moral accountability. International Journal of Transitional Justice, 1(1), 6-7.

${ }^{\text {i }}$ See for more details: J. Uyangoda, (2010), explaining how the state reformation after the war in 2009 has focused on less dynamic national reconciliation for greater peace achievements itself has become a challenge for ongoing political stability and sustainable solution to the ethnic question in Sri Lanka.

ii See for more details: Galtung's study on "positive peace" elaborating how violent in the formation of two aspects a) direct violence and b) structural violence forms cause tremendous harm to social justice of a society. The situation becomes more critical in a war tone society by making more structural harm. Therefore according to Galtung, "peace" achievements become challenging yet become important to be focused on elimination of structural injustices and differences.

iii See for more details: the work of Robert Schreiter, (2004). Punitive justice in more religious terms explained with reference to Christianity, Judaism and Islamism. In his explanation punitive/ retributive justice holds a similar meaning: punishment to "wrong-doing" and distributive justice as to achieve universal dignified life, restorative/ commutative justice as to give back as much as possible what has taken from them and finally structural justice in the establishment of correct social structural order.

${ }^{\text {iv }}$ See more details: K.M de Silva (1986), Uyangoda (1999), Hoglund and Orjuela (2013).

v The social integration policy of Sri Lanka (2012) after the end of war (1983-2009) declares social-coexistence through various policy implementations. Among them the language policy of Sri Lanka and religious harmony between three main ethnic groups i.e., Sinhala, Tamil and Muslims has become a vital objective. (Annual Report, Ministry of National Languages and Social Integration, 2012).

vi See for more details: The Final Report, Paranagama Commission (2017), “ Presidential Commission of Inquiry into Complaints of Abduction and Disappearances" referring the First 
Mandate, (2013), and the Second Mandate, (2014) detailed about the missing persons issues and including of violations to International Human Rights Law and International Humanitarian Law.

vii See for more details: Marcellin, S., \& Uyangoda, J. (2013). The book explains how political will of the country become a central element to decide on the peacebuilding in Sri Lanka.

viii See for more details: J. Goodhand, (2010). On how Sri Lanka as a "fragile state" become interesting in demilitarization and disengagement activities. The proposed "Sri Lankan- model" reflects its own direction for peace yet with heavy involvement through political influences.

ix See for more details: UN Human Rights Commission 2016 report 